\title{
Behavioral ecology of Oriental Magpie Robin Copsychus saularis
}

\author{
Jyoti Karna \\ Department of Zoology \\ Post Graduate Campus, Tribhuvan University, Biratnagar, Nepal \\ E-mail: karnajyoti@ymail.com
}

Key words: Robin, passerine, ecology, behavior, Biratnagar.

Oriental Magpie Robin is a small passerine Asian bird which was first recorded by Brian Hodgson. It is found in India, South China, Bangladesh, Pakistan, Indonesia, the Philippines, Sri Lanka, Malaysia, Singapore, Thailand, in tropical, Sub-tropical and temperate regions of Asia (Rasmussen \& Anderton, 2005). It is the national bird of Bangladesh.

In Nepal it is commonly found below $2000 \mathrm{~m}$. It is not found in arid area e.g. West Rajasthan. Oriental Magpie Robin is a common resident garden bird found in park, forest, cultivated areas and open woodlands close to human settlements in both cities as well as villages areas.

Every species of bird possesses some behavior which differ it from other species. It was interesting to note that species wise some different peculiar behaviors are found. Several ornithologists have described about Oriental Magpie Robin (Fleming et al., 1984; Grimmett et al., 2000; Ali, 2002). In case of the Oriental Magpie Robin, behavioral ecology such as feeding behavior, breeding behavior, nesting ecology, territorial behavior, social behavior, communicational behavior and singing behavior were observed and studied in Biratnagar, Nepal for one year.

\section{Feeding Behavior}

Oriental Magpie Robin was observed searching for food on the ground such as behind the kitchen where left-over had been disposed, around cow-shed, periphery of forest, streams, etc. hopping with raised tail and foraging for preys. The bird was seen feeding on insects and other invertebrates. The bird was also seen catching insects in mid-air and taking that to a perch to consume. It also preyed on ants by hopping on the grounds. Feeding on insects, the bird is found to have been insect controller in the garden.

\section{Breeding Behavior}

Oriental Magpie Robin breeds mainly from March to July in Nepal. Sexual dimorphism is found in this bird. During courtship displays, the male sang hearty and lusty song often at dawn and dusk and also in late afternoon from exposed perches. While singing, it moved its tail up and down in synchrony with the tune. At this period, the male often used to perch on tree tops or top of the buildings and sing. Sometimes the male was seen chasing female from tree to tree and sometimes under bushes. This sort of performance lasted till the female showed positive response for mating by perching on a twig making her head down.

\section{Nesting Ecology}

During observation Oriental Magpie Robin was seen nesting in tree hollows, in holes, in old brick walls of buildings or small holes left on the wall of building which the bird thinks is safe. The bird was seen to have used artificial nesting materials like nest boxes or bamboo provided 
by humans. Hay, grass and twigs were seen to have been used as nesting materials for making the cup-shaped nests. Hay provides warmth which is essential for egg incubation, twigs give it the structure and grass helps to deter predators. The female was seen equally involved in the nest building till the completion of the nest. Most probably nest building was completed a week before the eggs were laid. 4-5 eggs are laid in intervals of 24 hours and these are oval and usually pale blue green with brownish speckles which match the colour of hay. The eggs were incubated by the female alone for 13 days but 8-14 days (Pillai, 1956; Hume, 1890). Once hatched, the nestlings remain in the nest for another $14^{\text {th }}-16^{\text {th }}$ days before fledging. Females spend more effort on feeding the young than males but males share equally in all other domestic chores and spend more time on nest defense (Sethi \& Bhatt, 2007).

\section{Territorial Behavior}

Males were found shy and did not show territorial behavior by singing in winter. But they were found to have been quite aggressive and conspicuous in the breeding season and defended their territory jealously. They responded to the singing of intruders and even their reflections. Intruders were rebuffed with aggressive display showing the male with puffed out plumage, pointed bill upwards and strutting and posturing in front of the opponent. It may utter discordant calls while chasing intruders away from its territory. The average size of its territory was recorded to be about $1000 \mathrm{sq}$. $\mathrm{m}$. The male used to produce territorial calls to alert intruders.

\section{Notable Territorial Behavior}

Month painstaking observations were made to reach the confirmation which pair of chicks ultimately becomes successful in capturing and defending their parent. What was observed was that when chicks became able to search their food and learnt to protect by themselves from the predator, they were left alone by their patents at the vicinity of their nest. They used to chase away even their parents, if sometimes they visited them. This type of behavior was recorded when the chicks were able to defend their territory by themselves. The chicks which possessed dominant character became pair, then they took the position of territory defender of their parents nesting site. The new energetic pair forced to their parents and other weak pair left the place forever.

\section{Communicational Behavior}

During observation, Oriental Magpie Robin was found using two kinds of communicational behavior: first vocal by songs and calls; second by posturing: waging the tail, pecking, body presentation and flying.

Apart from song, the bird was seen using range of calls in a different ways such as territorial calls, emergence calls, roosting calls, threat calls, submissive calls, begging calls and distress calls.

\section{Singing Behavior}

During the study period, Oriental Magpie Robin was observed singing short songs during late summer. In winter, it almost remained silent but uttered sound to communicate with each other in low sound. With the advent of spring due to its gonad development, the male began to sing continuously sometimes for more than two hours by sitting on the top of naked branches of trees, bamboo, building, electric poles, wires, television antennae, etc. from where the bird could broadcast about his territory, attract a female and repel his competitors. This type of behavior 
was found to have been exhibited by a single male in search of a female for pairing, and also for many other purposes like mate guarding, mate recognition, parent-offspring recognition and neighbors-stranger discrimination.

I heard song of Oriental Magpie Robin at first in a spring morning, beginning at 4am or earlier. In other days, I found the bird uttering clear melodious song at dawn, repeated on short phrases and imitating other birds' calls such as calls of Drongo and songs of Oriole, Bulbul, Iora, etc. I listened to its song carefully for long duration and found varieties in its song. Generally it didn't change its singing spot before dawn but changed several times after dawn and flew undulating, with tail flicked open at every dip. The bird used to abruptly sing during the night too when temperature was suitable for singing.

Male Oriental magpie robin responded quickly when its song recorded was played from sound recorder in a very aggressive fashion, trying to find out the location of the song source. It came nearer to defend the approaching male. Once a singing male bird came nearer in response to the direction of sound after listening to its song from the song recorder played and when I stopped the song then it returned back to its own former place and started singing. The bird again came after some time when the song recorder was played again. It might be that the bird was trying to locate the direction the song was coming from. After the egg laying process commences, the bird was found singing less so as not to allure the predators.

\section{Acknowledgement}

I would like to sincerely acknowledge Dr. Bharat Raj Subba, a retired Associate Professor of Zoology Department, Post Graduate Campus (TU) Biratnagar for encouragement and his expertise in bird in preparing this article.

\section{References}

Ali, S. 2002. The Book of Indian Birds. Oxford University Press: Bombay Natural History Society.

Fleming, R.L. Sr., R.L Jr. Fleming \& L.S. Bangdel. 1984. Birds of Nepal. Kathmandu, Nepal: Nature Himalayas.

Grimmett, R., C. Inskipp \& T. Inskipp. 2000. Birds of Nepal. London: Christopher Helm.

Hume, A.O. 1890. The nests and eggs of Indian birds ( $2^{\text {nd }}$ Ed.). R.H. Porter, London. pp. 80-85.

Pillai, N.G. 1956. Incubation period and 'mortality rate' in a brood of the Magpie-Robin [Copsychus saularis (Linn.)]. J. Bombay Nat. Hist. Soc. 54(1): 182-183.

Rasmussen, P.C. \& J.C. Anderton. 2005. Birds of South Asia. The Ripley Guide. Volume 2. Smithsonian Institution and Lynx Edicions. 395p.

Sethi, V.K. \& D. Bhatt. 2007. Provisioning of young by the Oriental Magpie-robin. The Wilson Journal of Ornithology 119(3): 356-360. 